\title{
The Influence Of Jigsaw Type In Cooperative Learning Model On The Activity And Learning Outcomes By The Theme Of Globalization In The 6th Grade Of Min 1 Jombang
}

\author{
Luluk Wahyu Ningsih \\ Universitas Negeri Surabaya \\ Surabaya, Indonesia \\ lulukmhadi@gmail.com
}

\begin{abstract}
This study aims to observe the influence of the jigsaw type in cooperative learning model on the activity and learning outcomes by the theme of globalization in the 6th Grade of MIN I Jombang. This study was conducted in MIN I Jombang, specifically in VIC \& VID as the research subjects of the school year 2017/2018. This type of research is conducted experimental research to form the research design pretest-posttest control group design. The instrument used for collecting data are observation activity and learning outcomes. Item variables activity and learning outcomes have been tested through the test the validity of using the Product Moment correlation and reliability testing using Spearman-Brown with valid and reliable results. Test data normality using the Chi Kuadrat, while the homogeneity test and hypothesis testing using independent sample $t$ test formula with the results of both classes of normal distribution and homogeneous. The data has been collected and analyzed by t-test analysis by utilizing a computer system with a series statistical program (SPSS version 17). The result of the observation activity learn scored who dipresentase $96,5 \%$ in the category of very good. Based on the pretest on class experimentation and class control get value same and there is not yet the difference. After he received class treatment being handed out the course of this experiment in small allocations of posttest a class of the course of this experiment more robust than a class of control. So that it can be concluded that learning model cooperative type jigsaw could jazz up the activity and study results students a must MIN I Jombang
\end{abstract}

Keywords - Learning model cooperative type jigsaw , learning activity, learning outcomes

\section{INTRODUCTION}

The national curriculum enforced by the state of Indonesia for elementary/ MI level is the 2013 curriculum. The learning characteristic in this curriculum is thematic where the learning process based on theme combined with several subjects, including subjects of Natural Science (IPA), Bahasa Indonesia (BI), Citizenship Education (PKn), Arts and Culture (SBDP), and Social Studies (IPS). The learning themes of class VI (six) consists of 9 (nine) themes, each theme consists of 3 (three) sub themes where each sub theme consists of 6 (six) lessons. Each lesson is required to complete within a day. Within a week is expected one sub theme can be completed, so that within three weeks a theme can be mastered by learners.

In learning theme 4, class VI (six), about globalization, with subtheme 1 (one), discusses about the matter of globalization around me, while subtheme 2 (two) discusses about globalization and its benefits, and subtema 3 (three) discusses about love of homeland associated with globalization. Each sub-theme consists of 6 (six) lessons. The theme of globalization in class VI should be able to be learned by the students within three weeks, this limited time makes the materials are unfinished to study.

Based on the results of interviews with class VI teacher of MIN I Jombang, students have difficulty in mastering the material of globalization in a short time. In previous years the material of globalization was only studied in the subject of Social Studies, but in the 2013 curriculum the material of globalization becomes the theme in the thematic learning of class VI MIN I Jombang integrated in various other subjects covering Natural Science subjects with material saving electricity. Civics subject with our attitude in facing globalization, Bahasa Indonesia subject with learning to make reports, Social Studies with the theme of globalization discusses the relationship of cooperation between countries, the influence of globalization, the benefits of globalization, and foreign products.

The number of lesser-mastered subjects results low-grade of students' learning outcomes, it was proven by 5 students out of 32 students $(15 \%)$ who scored above the Minimum Learning Completion (KBM) and 27 students from 32 students $(85 \%)$ have not fulfilled the KBM. In addition, the average value of learning outcomes on the theme of Globalization in the previous year, 2016/2017 was 60. This is due to the material of globalization in the form of reading text.

The material is very much unbalanced compared to the available learning time. The number of books in school is not proportional for the number of students, resulting in less 
maximum of the books usage. Teaching process conducted by teachers tends to be conventional activities where activities are done by lecturing method and sometimes students make summaries from Electronic Student Book (BSE), so that the students learning tends to be passive. The students' activities in learning is only listening to the teacher explanations, writing Globalization material based on BSE books, then the teacher gives evaluations[1]. In explaining the material, the teacher tends to use lecturing method, so that the students' activities are just listening to the teacher's explanation on the material of globalization.

The above description asserts that (1) the lecturing method does not attract students' attention. In order to make an interesting learning process, students engagement is needed actively, creatively, and innovatively in it and (2) Thematic in 2013 Curriculum for SD / MI is not paid attention by students in general. However, if the learning materials are presented in a new form and the teacher creates an active and creative learning condition, then the learning of globalization theme in class VI can attract students' interest and attention.

Seeing from the above problems, the learning model that corresponds to the level of age of the students of Primary Grade VI and matches to the theme of globalization is Cooperative Learning Model-Jigsaw Type. The reason is that the students more quickly find and master the theme of globalization, if they discuss it in group, students will be able to connect information obtained with their background knowledge, students will be more sensitive and responsible for social problems, and have a high sense of brotherhood. In the learning, each group member learns each different problem, but will be the same in each group. Each representative from a different group will learn the same material. Then the results are brought to the original group where they have the responsibility to deliver the results to the group [2].

In order to improve the quality of national education through the improvement of quality of learning in the classroom, as well as seeing the thematic learning phenomena in MIN I Jombang now, it encourages author to examine the effect of learning by using Cooperative Learning Model-Jigsaw Type toward learning outcomes and student activities on globalization theme in class VI MIN I Jombang.

\section{RESEARCH METHOD}

Based on the problems of study, the design used in this study is quantitative research using experimental methods. The experimental method is suited best on research aimed at testing the consistency of theory and conformity to previous research. The quantitative research model aims to inform the impact of treatment on the experimental class through the Cooperative Learning Model-Jigsaw Type which is represented by (X) toward the activity and learning outcomes of class VI students on the Globalization theme which is denoted by (Y). This research involves two groups to be studied; those are control group and experimental group.
TABLE 1 RESEARCH DESIGN

\begin{tabular}{|c|c|c|c|c|}
\hline & Group & Pretest & Treatment & Posttest \\
\hline $\mathrm{R}$ & Experimental & $\mathrm{T} 1$ & $\mathrm{X}$ & $\mathrm{T} 2$ \\
\hline $\mathrm{R}$ & Control & $\mathrm{T} 1$ & - & $\mathrm{T} 2$ \\
\hline
\end{tabular}

[3]

\section{Explanation:}

$\mathrm{R}$ : Group Selection at random

T1 : Pretest on experimental group and control group

X : Cooperative Learning Model-Jigsaw Type

treatment on the experimental group

T2 : Posttest on experimental group and control group [4]

TABLE 2. NUMBER OF STUDENTS IN THIS RESEARCH

\begin{tabular}{|c|c|c|c|c|}
\hline Subject & \multirow{2}{*}{$\begin{array}{c}\text { Group/ } \\
\text { Observed }\end{array}$} & \multicolumn{2}{|c|}{ Gender } & \multirow{2}{*}{$\begin{array}{c}\text { Number } \\
\text { of } \\
\text { Students }\end{array}$} \\
\cline { 3 - 5 } & Female & Male & 29 \\
\hline $\begin{array}{c}\text { Control } \\
\text { Group }\end{array}$ & VI-C & 11 & 18 & 32 \\
\hline $\begin{array}{c}\text { Experimen } \\
\text { tal Group }\end{array}$ & VI-D & 15 & 17 & 61 \\
\hline \multicolumn{2}{|c|}{ Number of Students } & 26 & 35 & 61 \\
\hline
\end{tabular}

The data collection techniques of this research are as follow: (1) Observation, it was done by researcher both in teaching experiment class and control class with aim at observing activity that happened during learning process, and (2) Tests, those were conducted through pretest and posttest, in the control class as well as in the experimental class. Pretest was done so that researcher knew the initial state of the learners while the posttest was done to know the final condition of the students after experiencing the treatment. Moreover, the Research Instruments used are (1) Observation Sheet Activity Students, and (2) Pretest and Posttest Test Sheet.

The instrument test technique used is validity test and reliability test to prove that the instrument prepared by the researcher is good. Next, the requirements test is applied, this analysis is necessary to determine the hypothesis testing can be continued or not. Some data analysis techniques need requirements test analysis. Variant analysis requires that the research data come from normally distributed populations and groups that are homogeneous. Hence, the analysis of variants requires test of normality and homogeneity of data.

The first data analysis technique used to observe the learning activity level of the learner is quantitative descriptive, it is done through observation sheet of learners activities implemented during teaching and learning in control group and experiment group, where the evidence of observation result is then analyzed by following formula: 


$$
\mathrm{P}=\frac{f}{N} \times 100 \%
$$

Notes:

$\mathrm{P} \quad$ : Percentage

$\mathrm{f} \quad$ : The score of the number of activities performed

$\mathrm{N} \quad$ : the score of total activities

Predicate assessment results:

$$
\begin{array}{lr}
\text { Very High } & =80 \%-100 \% \\
\text { High } & =60 \%-79 \%
\end{array}
$$

Second, $\mathrm{t}$ test data analysis for posttest between control class group and experiment group to know its difference. The $t$ test is done to know the result of significance test of association between $\mathrm{X}$ and $\mathrm{Y}$ variables, whether $\mathrm{X}$ variable (using Cooperative Learning Model-Jigsaw Type) proved to be able to influence $\mathrm{Y}$ variable (learning outcomes and learning activity of Class VI students in MIN Kauman Utara Jombang) separately or partially. The t-test formula is shown in the figure below:

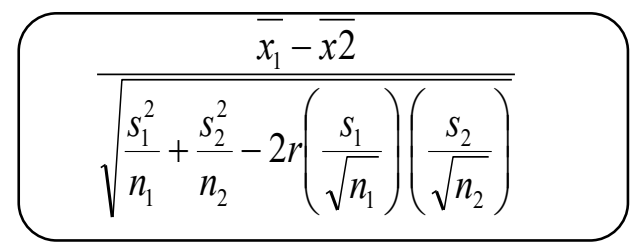

[6][7]

$$
\begin{array}{ll}
\text { Annotation: } \\
\begin{array}{ll}
\overline{x_{1}} & \text { : Mean sample } 1 \\
\overline{x_{2}} & \text { : Mean sample } 2 \\
\mathrm{~s}_{1} & \text { : Standard deviation sample } 1 \\
\mathrm{~s}_{2} & \text { : Standard deviation sample } 2 \\
\mathrm{~s}_{1}{ }^{2} & \text { : Variance sample } 1 \\
\mathrm{~s}_{2}{ }^{2} & \text { : Variance sample } 2 \\
\mathrm{r} & \text { : Correlation between two samples }
\end{array}
\end{array}
$$

Basic decision-making based on comparative $t_{\text {calculate }}$ and $t_{\text {table }}$ with description:

a. If $t_{\text {calculate }}$ is larger than $t_{\text {table }}\left(t_{\text {calculate }}>t_{\text {table }}\right)$, then the null hypothesis (Ho) proposed is rejected and alternative hypothesis $(\mathrm{Ha})$ is accepted.

b. If $t_{\text {calculate }}$ is smaller than $t_{\text {table }}\left(t_{\text {calculate }}<t_{\text {table }}\right)$, then the null hypothesis (Ho) proposed is accepted and the alternative hypothesis $(\mathrm{Ha})$ is rejected.

Ho: There is no difference in activity and learning outcomes of students participating Cooperative
Learning Model-Jigsaw Type with conventional learning.

Ha: There is a difference in activity and learning outcomes of students participating Cooperative Learning Model-Jigsaw Type with conventional learning.[8]

\section{RESULTS AND DISCUSSION}

\section{A. Instrument Test Analysis}

The Analysis of instrument test is used to measure the validity of the questionnaire in this study, the author uses SPSS software version 15.00 and then will compare the value of $r$ in the column Corrected Item Total Correlation> $r$ table then the statement items are considered valid, this is done so that the research instrument can be known whether good and worthy to be used as a research instrument.

The validity test was conducted on 32 students where the whole student is the member of population, but outside of the research sample. Validity test is done through comparison between rcalculate values to rtable. The value of rcalculate will be compared with rtable based on case count 32 of 0349 with $\alpha=0,05$ (alpha 5\%), If rcalculate bigger than rtable and has positive value hence item or question or indicator is declared valid (Ghozali, 2011:53).

TABLE 3. QUESTIONNAIRE VALIDITY TEST

\begin{tabular}{|c|c|c|c|}
\hline Items & $\begin{array}{c}\text { Questioner } \\
\text { Variables }\end{array}$ & $\begin{array}{c}\text { Limit } \\
\text { Value }\end{array}$ & Annotation \\
\hline item 1 & 0.391 & 0.349 & Valid \\
\hline Item 2 & 0.470 & 0.349 & Valid \\
\hline Item 3 & 0.676 & 0.349 & Valid \\
\hline Item 4 & 0.386 & 0.349 & Valid \\
\hline Item 5 & 0.457 & 0.349 & Valid \\
\hline Item 6 & 0.172 & 0.349 & Invalid \\
\hline Item 7 & 0.257 & 0.349 & Invalid \\
\hline Item 8 & 0.597 & 0.349 & Valid \\
\hline Item 9 & 0.515 & 0.349 & Valid \\
\hline Item 10 & 0.761 & 0.349 & Valid \\
\hline Item 11 & 0.657 & 0.349 & Valid \\
\hline Item 12 & 0.257 & 0.349 & Invalid \\
\hline Item 13 & 0.648 & 0.349 & Valid \\
\hline Item 14 & 0.653 & 0.349 & Valid \\
\hline Item 15 & 0.742 & 0.349 & Valid \\
\hline Item 16 & 0.608 & 0.349 & Valid \\
\hline
\end{tabular}




\begin{tabular}{|c|c|c|c|}
\hline Item 17 & 0.446 & 0.349 & Valid \\
\hline Item 18 & 0.439 & 0.349 & Valid \\
\hline Item 19 & 0.725 & 0.349 & Valid \\
\hline Item 20 & 0.391 & 0.349 & Valid \\
\hline Item 21 & 0.034 & 0.349 & Invalid \\
\hline Item 22 & 0.151 & 0.349 & Invalid \\
\hline Item 23 & 0.673 & 0.349 & Valid \\
\hline Item 24 & 0.562 & 0.349 & Valid \\
\hline Item 25 & 0.693 & 0.349 & Valid \\
\hline
\end{tabular}

TABEL 5. PRETEST NORMALITY TEST

\begin{tabular}{|c|c|c|c|c|c|c|c|}
\hline \multirow{4}{*}{$\begin{array}{l}\text { Pret } \\
\text { est }\end{array}$} & \multirow[t]{2}{*}{ Group } & \multicolumn{3}{|c|}{$\begin{array}{c}\text { Kolmogorov- } \\
\text { Smirnov(a) }\end{array}$} & \multicolumn{3}{|c|}{ Shapiro-Wilk } \\
\hline & & Statistic & $\mathrm{df}$ & Sig. & Statistic & $\mathrm{df}$ & Sig. \\
\hline & Experimental &, 150 & 32 &, 064 & ,913 & 32 &, 013 \\
\hline & Control & , 147 & 29 &, 110 & ,950 & 29 &, 180 \\
\hline
\end{tabular}

Based on the output of the Pretest Normality Test Table, there are significant values for the learning outcomes with the use of the pretest try out of 0.064 (for the experimental class) and the value of 0.110 (for the control class). Since both the value of learning result variable with the use of the test of pretest above is greater than $>0,05$ it can be concluded that the data is spread / distributed normally, so it can be analyzed with parametric statistics.

Homogeneity Test is a test to measure whether two or more distributions are the same variance or not. Homogeneity is an assumption test, which in this study is used Test of Homogeneity of Variance.

\section{TABEL 6. HOMOGENEITY TEST} question is consistent or stable over time. In SPSS there are facilities that can be used to measure reliability, it is through Cronbach's Alpha statistical test and variable is reliable if the value of Cronbach's Alpha $>0.70$ (Ghozali, 2011:48). Based on the reliability test results as follows:

\section{TABLE 4. QUESTIONNAIRE RELIABILITY TEST}

\begin{tabular}{|c|c|c|c|c|}
\hline $\begin{array}{c}\text { Question } \\
\text { naire } \\
\text { Variable }\end{array}$ & $\begin{array}{c}\text { Number } \\
\text { of } \\
\text { Question } \\
\text { s }\end{array}$ & $\begin{array}{c}\text { Reliabilit } \\
\mathbf{y} \\
\text { Coefficie } \\
\text { nt }\end{array}$ & $\begin{array}{c}\text { Criti } \\
\text { cal } \\
\text { Poin } \\
\text { t }\end{array}$ & $\begin{array}{c}\text { Annotati } \\
\text { on }\end{array}$ \\
\hline Y & 25 & 0,907 & 0,70 & Reliable \\
\hline
\end{tabular}

Source: Questionnaire data that has been processed through SPSS

Statistical table of reliability above on dependent variable of posttest questions shows the value of Cronbach's Alpha $(0.907)>0.70$, then it can be concluded that the instrument items are reliable.

The test of requirements for the application of the analysis using t-test 2 independent samples of the research variable data, then from the pretest results must meet the requirements or meet the assumptions that include the normality test and homogeneity test.

Normality Test of the results of this study was conducted by using Lilliefors Test Technique (KolmogorovSmirnov test), which is summarized in the following expositions:

\begin{tabular}{|rc|r|r|r|r|}
\hline \multicolumn{1}{|c|}{ TABEL 6. HOMOGENEITY TEST } \\
\hline result & $\begin{array}{c}\text { Levene } \\
\text { Statistic }\end{array}$ & df1 & \multicolumn{1}{c|}{ df2 } & Sig. \\
\hline $\begin{array}{c}\text { Based on } \\
\text { Mean } \\
\text { Based on } \\
\text { Median } \\
\text { Based on } \\
\text { Median } \\
\text { and with } \\
\text { adjusted } \\
\text { df } \\
\text { Based on } \\
\text { trimmed } \\
\text { mean }\end{array}$ & 1.348 & 1 & 59 & .142 \\
& 1.870 & 1 & 51.851 & .250 \\
\hline
\end{tabular}

Based on the above table it is known that the significance value of 0.142 , then the value of 0.142 above greater than $>$ 0.05 and thus can be concluded the data in the second condition of the sample is Homogeny.

\section{B. Students'Activities Data Analysis}

Data Analysis of the Students Learning Activities are descriptive quantitative used to indicate the influence of students' activities between experimental class and control class. 
TABLE 7.DATA ANALYSIS OF STUDENTS' LEARNING ACTIVITIES

\begin{tabular}{|c|c|c|c|}
\hline \multirow{2}{*}{ No } & \multirow{2}{*}{$\begin{array}{l}\text { Aspects } \\
\text { observed }\end{array}$} & \multicolumn{2}{|l|}{ Group } \\
\hline & & Control & Experimental \\
\hline 1 & Reading & $63 \%$ & $82 \%$ \\
\hline 2 & Writing & $61 \%$ & $76 \%$ \\
\hline 3 & $\begin{array}{l}\text { Discuss with } \\
\text { the teacher }\end{array}$ & $63 \%$ & $75 \%$ \\
\hline 4 & $\begin{array}{l}\text { Discuss with } \\
\text { group }\end{array}$ & $64 \%$ & $86 \%$ \\
\hline 5 & Communicating & $62 \%$ & $80 \%$ \\
\hline \multicolumn{2}{|c|}{ Average Percentage } & $63 \%$ & $80 \%$ \\
\hline
\end{tabular}

Based on table 7 above, the result of comparison of students' activities from control class has average percentage $63 \%$ from all observed aspects, while experimental class has average percentage $80 \%$, meaning that the percentage of students' activities of experimental group is bigger than control group, $80 \%$ have very high predicate. Based on data analysis, it is obtained that learning process by using Cooperative Learning Model-Jigsaw Type has a significant influence on the activities of students compared with conventional learning.

\section{Two Independent Samples T Test Analysis}

With the fulfillment of the assumption of normality and homogeneity of variance as disclosed above, the two independent samples $t$ test can be applied.

TABEL 8. DESCRIPTIVE STATISTICS Group Statistics

\begin{tabular}{|cc|c|c|c|c|}
\hline & Group & $\mathrm{N}$ & Mean & $\begin{array}{c}\text { Std. } \\
\text { Deviation }\end{array}$ & $\begin{array}{c}\text { Std. Error } \\
\text { Mean }\end{array}$ \\
\hline result & $\begin{array}{c}\text { Experi } \\
\text { mental }\end{array}$ & 32 & 91.06 & 6.247 & 1.104 \\
& Control & 29 & 76.07 & 5.014 & .931 \\
\hline
\end{tabular}

TABLE 9. TWO INDEPENDENT SAMPLES T TEST RESULT

\begin{tabular}{|c|c|c|c|c|c|c|c|c|c|}
\hline & \multicolumn{2}{|c|}{$\begin{array}{c}\text { Levene' } \\
\text { s Test } \\
\text { for } \\
\text { Equalit } \\
\text { y of } \\
\text { Varianc } \\
\text { es }\end{array}$} & \multicolumn{7}{|c|}{ t-test for Equality of Means } \\
\hline & $\mathrm{F}$ & $\begin{array}{l}\mathrm{Si} \\
\text { g. }\end{array}$ & $\mathrm{t}$ & $\mathrm{df}$ & $\begin{array}{l}\text { Sig. } \\
(2- \\
\text { taile } \\
\text { d) }\end{array}$ & $\begin{array}{c}\text { Mea } \\
n \\
\text { Diff } \\
\text { eren } \\
\text { ce }\end{array}$ & $\begin{array}{l}\text { St } \\
\text { d. } \\
\text { Er } \\
\text { ror } \\
\text { Di } \\
\text { ffe } \\
\text { re } \\
\text { nc }\end{array}$ & $\begin{array}{r}95 \\
\text { Cor } \\
n \\
\text { Inte } \\
\text { of } \\
\text { Dif } \\
n\end{array}$ & $\begin{array}{l}\% \\
\text { fide } \\
\text { e } \\
\text { rval } \\
\text { he } \\
\text { ere } \\
\text { e }\end{array}$ \\
\hline $\begin{array}{cc}\mathrm{r} & \text { Equ } \\
\mathrm{e} & \mathrm{al} \\
\mathrm{s} & \text { vari } \\
\mathrm{u} & \text { ance } \\
\mathrm{l} & \mathrm{s} \\
\mathrm{t} & \text { assu } \\
& \text { med } \\
& \text { Equ } \\
\text { al } \\
\text { vari } \\
\text { ance } \\
\mathrm{s} \\
\text { not } \\
\text { assu } \\
\text { med }\end{array}$ & $\begin{array}{c}2 . \\
12 \\
8\end{array}$ & $\begin{array}{l}.1 \\
50\end{array}$ & $\begin{array}{c}10 \\
.2 \\
68\end{array}$ & $\begin{array}{c}58 \\
.1 \\
84\end{array}$ & .000 & $\begin{array}{c}14.9 \\
94\end{array}$ & $\begin{array}{c}1 . \\
44 \\
4\end{array}$ & $\begin{array}{c}12 \\
.0 \\
72\end{array}$ & $\begin{array}{c}17 \\
.9 \\
15\end{array}$ \\
\hline
\end{tabular}

\section{CONCLUSIONS AND SUGGESTIONS}

In relation to the results of the research analysis discussed above, so as the research findings can be concluded that: 1) The significant influence of the Cooperative Learning Model-Jigsaw Type on the learner's activities, it is based on the result of comparison of the students' activities from the control group which has $63 \%$, while experimental group have an average percentage of $80 \%$, it means that the percentage of the experimental group is greater than the control one with a very high predicate. 2) There is a significant influence between Cooperative Learning Model-Jigsaw Type on the learning outcomes of grade VI students in MIN 1 Jombang, this is proved by the position of $t_{\text {calculate }} 10,268$ larger than $t_{\text {table, }}$, and significant level 0,000 in which its position is still far below $\alpha 0.05$ (alpha 5\%), and conventional one. 
Based on the results of the research concluded above, it can be proposed suggestions to improve student activities and learning outcomes are, those are: 1) for students, the implementation of Cooperative Learning Model-Jigsaw Type is expected to be done in learning other learning materials; 2) for teachers, learning should apply the use of new learning models such as Cooperative Learning Model-Jigsaw Type to improve its learning quality so that success in teaching and learning process in class can be achieved; 3 ) for the Madrasah Principal, As a consideration for Madrasah Principal to conduct studies for teachers in implementing learning in the classroom and applying various models of cooperative learning; and 4) For other researchers, as reference material for further research on Cooperative Learning Model-Jigsaw Type.

\section{REFERENCES}

[1] S. Arikunto, Dasar-dasar evaluasi pendidikan. Bumi Aksara, 1999.
[2] D. K. Rusman and C. Riyana, "Pembelajaran Berbasis Teknologi Informasi dan Komunikasi," Bandung Rajawali Pers, 2011.

[3] M. P. P. Sukardi, "Kompetensi dan Praktiknya, Jakarta: PT," Bumi Aksara, 2003.

[4] R. E. Slavin, "Cooperative learning teori, riset dan praktik," Bandung Nusa Media, vol. 236, 2005.

[5] H. Wasito, Pengantar metodologi penelitian: buku panduan mahasiswa. PT Gramedia Pustaka Utama, 1997.

[6] Sugiyono, Metode penelitian pendidikan:(pendekatan kuantitatif, kualitatif dan $R \& D$ ). Alfabeta, 2008.

[7] M. P. K. Sugiyono, "Kualitatif, dan Kombinasi (Mixed Methods)," Bandung Alf., 2013.

[8] S. F. Rodiyansyah, H. Sutarno, and P. Siahaan, "Studi Komparasi antara Hasil Pembelajaran Berbasis Komputer Menggunakan Metode Cooperative Learning Tipe Jigsaw dengan Metode Konvensional," J. Pendidik. Teknol. Inf. dan Komun., vol. 2, no. 2, pp. 47-52, 2009. 